DOI: 10.17707/AgricultForest.62.1.11

Emmanuel.Olasope BAMIGBOYE ${ }^{I}$

\title{
UTILISATION OF INDIGENOUS KNOWLEDGE SYSTEMS FOR SUSTAINABLE VEGETABLE PRODUCTION IN EKITI STATE: IMPLICATIONS FOR SUSTAINABLE AGRICULTURAL DEVELOPMENT IN NIGERIA
}

\begin{abstract}
SUMMARY
Vegetable production is often faced with some challenges that borders on pests and diseases infestation and low yield. Therefore, this study explores indigenous knowledge system (IKS) approaches in vegetable production under tropical conditions. The following were examined: personal attributes of vegetable farmers, identification of various vegetables production stages with their corresponding IKS approaches, presentation of procedures used in developing some of the IKS amongst farmers, identification of reasons for using IKS in vegetable production and examination of benefits and problems associated with IKS utilization in vegetable production. Frequency distribution, percentages, mean and standard deviation were used to describe the data. Inferential statistics such as correlation was used in analysis. There was a relationship between IKS approaches used in vegetable production and personal attributes age, farm size, household size, and income. Reasons for using IKS included: hazards involved in utilisation of synthetic fertilizers, less financial commitment in processing of material, and it is environmental friendly. Benefits and problems associated with IKS were: 'it is profitable', 'it is cheaper than modern method', and 'it increases farm revenue'. Some IKS used in vegetable production include: bush fallow, trash burning, bed and heap making, soil incorporated with weathered poultry manure used to control nematode in tomatoes, extracts of occimum to control damping off. Others include application with lotion from black local soap and dusting with wood ash from Iroko tree (Chlorophora excels) to control insects. Constraints to production and IKS must be improved and to forestall IKS being supplanted for use in sustainable agricultural development in Nigeria.
\end{abstract}

Keywords: farmer, hazard, pests and diseases and agricultural development

\section{INTRODUCTION}

Vegetable production has always been an integral part of traditional farming systems in developing countries. (Awujoola, 2007). Vegetables are

\footnotetext{
${ }^{1}$ Emmanuel.Olasope BAMIGBOYE, (corresponding author: tayo_bamigboye@yahoo.co.uk, tayoobamigboye@gmail.com), Department of Agricultural Extension and Rural Development, Obafemi Awolowo University, Ile-Ife, Osun State, NIGERIA

Paper presented at the $6^{\text {th }}$ International Scientific Agricultural Symposium "AGROSYM 2015"

Notes: The authors declare that they have no conflicts of interest. Authorship Form signed online.
} 
needed in households in the tropics to enhance, or improve, intake of balanced diets and they serves as a source of income to small producers (Rubsihayo, 1994). Demand for vegetables has increased as a result of urbanization, industrialization, growth in population and diversification of eating habits (Rubaihayo. 1992).

Vegetable gardening practices promote variety in diets and improve household nutrition of rural populations. In spite of vegetable improvement programs which produce high yielding, early maturing, disease resistant varieties and extension services to boost production in developing nations, there is reluctance by producers to adopt scientific knowledge.

Atteh(1990) and Bamigboye \& Kuponiyi (2009) noted that most scientific knowledge failed because of assumed superiority of western technologies and the body of knowledge by small scale producers. Kolawole (2002) claimed that rural people, to whom all research development efforts are directed, have their own body of knowledge that enables them to arrive at decision which would help better their lots. Brokensha et al. (1980) stated "to ignore rural peoples knowledge is to ensure failure in development". This is because local people respects the expertise of indigenous people which is regarded as a major contribution to development (Osunade 1996). The development and use of local knowledge including agricultural practices is generally believed to conform to ecologically sound land management systems.

The study was undertaken to investigate utilisation of indigenous knowledge systems for sustainable vegetable production in Ekiti State, Nigeria. Specifically it was undertaken to:

a) describe personal attributes of vegetable farmers in the study area,

b) identify various vegetable production stages and their corresponding IKS approaches,

c) present procedures used in developing and utilising some of the IKS among farmers,

d) identify reasons for using IKS in vegetable production and examine benefits and problems associated with IKS utilization in vegetable production.

\section{MATERIAL AND METHODS}

The study area was Ekiti state in south-western Nigeria located between 40o 20' and 5o 40' east longitude and between 6o20'and 80 10' north latitude. Ekiti state is comprised of 16 Local Government Areas (LGA). Farming is a widespread occupation

A multistage sampling technique was used to select respondents. The first step involved purposive selection of 5 LGAs from the 16 LGAs in the state based on the concentration of vegetable farmers. Two communities were then randomly selected from each of the LGA, making ten communities. Using simple random sampling technique, 10 respondents were sampled all 100 vegetable farmers were 
sampled Validated and pretested structured interview schedule was used to elicit requisite information from the respondents between April and May, 2014.

Data analysis procedure

The simple descriptive statistics frequency, percentage, mean and standard deviation were used to describe the data while Pearson Correlation was used to make inferential deductions on the relationship between IKS utilization and personal characteristics of the vegetable farmers

\section{RESULTS AND DISCUSSION}

Personal characteristics of respondents (Table 1) varied. The majority of respondents are in the active years of life. There are more female vegetable farmers than males, and (corroborate) findings of (Rubaihajo, 1994). The average family size varied but suggested it was made up of husband, wife, children and dependant relatives, Most respondents had a below average family income. Almost all respondents had some education.

Table 1. Frequency and percentage distribution of socio-economic characteristics of sampled vegetable farmers in Ekiti state, Nigeria

\begin{tabular}{|l|c|c|}
\hline Socio-economic characteristics & Frequency & Percentage $\mathbf{n} \mathbf{1 0 0}$ \\
\hline Age & & 20 \\
Below 35 & 20 & 64 \\
Between 49 and 59 & 64 & 16 \\
64+ & 16 & 100 \\
Total & 100 & \\
\hline Gender & & 30 \\
Male & 30 & 70 \\
Female & 70 & 100 \\
Total & 100 & \\
\hline Household size & & 60 \\
1 to 5 & 60 & 25 \\
6 to 10 & 25 & 15 \\
$11+$ & 15 & 100 \\
Total & 100 & \\
\hline Income (Naira) & & 58 \\
93,580 & 58 & 19 \\
58,966.5 & 19 & 15 \\
24,351 & 15 & 8 \\
> 100,000 & 8 & 100 \\
Total & 100 & \\
\hline Education & & 36 \\
Primary education & 36 & 25 \\
Post secondary & 25 & 29 \\
Secondary & 29 & 10 \\
None & 10 & 100 \\
Total & 100 & \\
\hline
\end{tabular}


The IKS utilized in vegetable production varied (Table 2). The great majority utilized slashing and trash burning for land clearing. The [assumption] was that during burning most soil dwelling insects would have been destroyed and the refuse would add potash to the soil. Other methods were employed for soil fertility management. A minority used ogirisoko lotion to treat seed before planting to protect against soil dwelling insects.

Control of nematodes and pest of okra and tomato (Solanum lycopersicum L) were used, and other methods were used for above ground insects. Methods were used to control damping off a fungal disease of tomatoes and pepper (Capsicum annuum L.) The IKS are highly utilized in vegetable production in the study area. The finding support the report of Kolawole (2002) that no matter the degree of modernity, people will still use what is known to them.

Table 2. Distribution of respondents by the types of IKS utilize in vegetable production (2013)

\begin{tabular}{|c|c|c|c|}
\hline $\begin{array}{l}\text { Stages of } \\
\text { production }\end{array}$ & Corresponding IKs & Frequency & Percentage \\
\hline $\begin{array}{l}\text { Land preparation } \\
\text { Slashing without } \\
\text { burning } \\
\text { Slashing and trash } \\
\text { burning } \\
\text { Heap and bed } \\
\text { making } \\
\end{array}$ & Cutlass & $\begin{array}{l}25 \\
80 \\
65 \\
35\end{array}$ & $\begin{array}{l}25 \\
80 \\
65 \\
35\end{array}$ \\
\hline Sowing Seed & $\begin{array}{l}\text { Treated seeds with ogirisoko portion } \\
\text { to guide against soil dwelling insects }\end{array}$ & 40 & 40 \\
\hline $\begin{array}{l}\text { Soil fertility } \\
\text { management }\end{array}$ & $\begin{array}{c}\text { Organic manuring } \\
\text { Bush fallow } \\
\text { Cover cropping } \\
\text { Crop rotation } \\
\end{array}$ & $\begin{array}{c}60 \\
72 \\
40 \\
5 \\
\end{array}$ & $\begin{array}{c}60 \\
72 \\
40 \\
5 \\
\end{array}$ \\
\hline Weed control & Manual (using hoe) & 100 & 100 \\
\hline $\begin{array}{l}\text { Pest and nematode } \\
\text { control }\end{array}$ & $\begin{array}{l}\text { Soil incorporated with weathered } \\
\text { poultry manure } \\
\text { Extract of siam weed and neem }\end{array}$ & $\begin{array}{l}59 \\
15\end{array}$ & $\begin{array}{l}59 \\
15\end{array}$ \\
\hline $\begin{array}{l}\text { Defoliating insect } \\
\text { Control }\end{array}$ & Dusting from iroko wood ash & 50 & 50 \\
\hline $\begin{array}{l}\text { Disease control } \\
\text { Damping off } \\
\text { tomatoe and pepper }\end{array}$ & $\begin{array}{l}\text { Black local soap } \\
\text { Spray with occimum portion }\end{array}$ & $\begin{array}{l}45 \\
48\end{array}$ & $\begin{array}{l}45 \\
48\end{array}$ \\
\hline
\end{tabular}


The majority of respondents indicated that IKS was less hazardous had less financial commitment are available as reasons for using it in vegetable production (Table 3). A smaller subset use IK it is environmentally friendly.

Table 3. Reasons for using IKS

\begin{tabular}{|l|c|c|}
\hline Reasons for using IKS & Frequency & Percent \\
\hline Less hazardous & 80 & 80 \\
\hline $\begin{array}{l}\text { Less financial commitment in processing of material } \\
\text { involved }\end{array}$ & 62 & 62 \\
\hline It is environmental friendly & 40 & 40 \\
\hline It is readily available & 65 & 65 \\
\hline
\end{tabular}

Better than half of respondents indicated that energy is dissipated during preparation and utilization of most IKS causing a problem to its utilization (Table 4). A smaller subset indicated that elders who are the major custodians of the IKS are not willing to divulge the knowledge. The serious implication is that most of the IKS are not being documented and can be lost. A little better than half felt that the odor is disagreeable, this may be curtailed through proper standardization.

Table 4. Problems associated with the use of IKS

\begin{tabular}{|l|c|c|}
\hline Reason & Frequency & Percent \\
\hline $\begin{array}{l}\text { The odor could be offensive at times e.g. neem } \\
\text { during extraction }\end{array}$ & 55 & 55 \\
\hline $\begin{array}{l}\text { A great of energy consumed during preparation } \\
\text { and utilization }\end{array}$ & 60 & 60 \\
\hline $\begin{array}{l}\text { Custodians of indigenous knowledge are not } \\
\text { willing to knowledge }\end{array}$ & 45 & 45 \\
\hline
\end{tabular}

Multiple responses

Source: Field survey, 2014

Four personal characteristics of vegetable farmers had positive and significant relationships with IKS utilization (Table 5). The positive correlation of age, household size, income and farm size indicated that the greater the variation in these variables, the more IKS producers utilized in vegetable production. 
Table 5. Correlation analysis showing relationships between IKS utilization and socio-economic characteristics of vegetable farmers

\begin{tabular}{|l|l|lr|l|}
\hline $\begin{array}{l}\text { Socio-economic } \\
\text { characteristic of } \\
\text { vegetable farmers }\end{array}$ & $\begin{array}{l}\text { Correlation } \\
\text { coefficient }\end{array}$ & $\begin{array}{l}\text { Coefficient of } \\
\text { determination } \\
\text { (COD) }\end{array}$ & \%Contribution \\
\hline Age & 0.359 & $0.1288^{*}$ & 12.8 \\
Household size & 0.118 & $0.0139^{* *}$ & 1.39 \\
Income & 0.322 & $0.159^{* *}$ & 15.9 \\
Farm size & 0.380 & $0.144^{*}$ & 14.44 \\
Education level & -0.076 & $0.0057 \mathrm{NS}$ & 0.58 \\
\hline
\end{tabular}

*Significant at $0.05 * *$ significant at 0.01

The implications are: since experience is a product of age, the older the farmer is the more experience he had in farming and the more local methods were used. Also, the larger the household size (which may serve as farm support) the more IKSs were used. The large with a tendency of variation of crops. The higher the income generated the more IKS practiced indicating that if something works it would be adapted. The negative correlation between education and IKS utilization would tends towards western methods of farming (Deji et al., 2005; Bamigboye, 2008).

\section{CONCLUSIONS}

The types of IKS utilized in the vegetable production in the study area were: soil incorporated with weathered poultry manure, extracts of occimum to control damping off and dusting with wood ash from Chlorophora excels. Some of the principal problems militating against the use of IKS in vegetable production were: custodian of indigenous knowledge are not willing to diverge their knowledge and the odor could offensive during preparation and usage It is therefore recommended that scientists should mainstream indigenous people into research cycle for holistic rural development.

\section{REFERENCES}

Indigenous knowledge and local level development (1992). The participatory approach. Paper presented at the International Symposium on Indigenous Knowledge and sustainable development: 1.1.R.R., the Philippines, 20-26 September.

Awojoola A.I. (2007). Practical manual for students of agriculture volume 1 (Reversed edition) page 56 ISBN 978-8027-83-6 published and printed by Odumatt press and publishers, Oba Adeyemi High Scholl Road Oyo, Nigeria.

Kuponiyi F.A. and Bamigboye E.O. (2009). The use of indigenous knowledge systems IKS in rice production by farmers in Ekiti state, Nigeria International Journal of Agricultural Economics and Rural Development, Volume 2., page 68.

Bamigboye E.O. (2008). Factor associated with the utilization of IKS for Rice production by Farmers in Ekiti State, Nigeria. Unpublished M.tech thesis, Department of Agricultural Economics and Extension, LAUTECH Ogbomoso, Nigeria. 
Brokensha, D.D., Warren, D.M. and Werner. O. (eds) (1980). Indigenous Knowledge Systems and Development, Lanham University Press of America pp.1-10

Deji, O.F., Adereti, F.O. and Ilori (2005). Factor Associated with female headed household to selected Agricultural production Resources, Osun State, Nigeria. Journal of Rural Sociology volume 5 (number 1 and 2) October 2005, page 45.

Kolawole O.D., (2002): Local Knowledge Utilization and sustainable Rural Development in the 21st century. The Hague, Indigenous Knowledge and Development Monitor 9 (3) pp.13-25.

Midmore, D.j., Vera Nines and Venkataraman, R. (1991) "House gardening project in Asia past experience and future direction" Technical Bulletin number 19 Asian vegetable research and development centre.

Rubaihayo, E.B. (1994). Indigenous vegetables of Uganda. African crop science proceedings 1, 120-124.

Osunade, M.A. (1996). Research in Indigenous Knowledge Systems for sustainable Agricultural development. A paper delivered at workshop in indigenous knowledge and biotechnology poly consult seminar room. The polytechnic Ibadan pp. 1-8. 